\title{
THE UTILIZATION OF ORGANIC PHOSPHORUS BY PHYTOPLANKTON
}

\author{
By S. P. Chu \\ Ray Lankester Investigator at the Plymouth Laboratory
}

The rate at which phosphorus and nitrogen are used by plants, returned to the water and again utilized, is a direct measure of the fertility of the sea (Harvey, 1942, p. 233). A knowledge of the processes of the cycle of such changes is important for the study of marine productivity. The nitrogen cycle has received much attention and much work has been done (Cooper, I937; Harvey, I940), but little is yet known about the cycle of phosphorus. The present investigation is intended to clarify a few of the processes in the phosphorus cycle.

Phosphorus in the sea is known to occur in living organisms, in particulate and dissolved organic material, and as dissolved inorganic phosphorus (of which only orthophosphate is known to be present). Phosphorus in living and particulate material becomes eventually dissolved in water as organic or inorganic phosphorus, and the dissolved organic phosphorus can turn into inorganic phosphorus through various agencies. It is only the dissolved phosphorus that can be used directly by plants, and it is generally assumed that only phosphate is being absorbed and utilized by plants in the sea. We have practically no knowledge of the other forms of phosphorus that can be utilized by marine plants. Harvey (I940) has demonstrated that phytoplanktonic diatoms may utilize ammonium nitrogen in preference to nitrate nitrogen, and that they can also utilize some organic substances, such as urea and uric acid, as sources of nitrogen. It is of interest to know whether they can use phosphorus from sources other than orthophosphate. In the following experiment parallel cultures were made with orthophosphate, pyrophosphate and phytin supplied as sources of phosphorus with a view to finding out whether diatoms can utilize the last two as effectively as they utilize orthophosphate. Phytin was chosen as it has been considered a stable organic phosphorus compound of plant origin.

Exp. I. Sea water collected from the mouth of Plymouth Sound early in April was enriched with potassium nitrate giving a nitrogen concentration of $2000 \mathrm{mg}$. $/ \mathrm{m} .^{3}$ with an iron concentration of $50 \mathrm{mg} . / \mathrm{m} .^{3}$ added in the form of ferric citrate. The original content of phosphate phosphorus in the sea water was $7 \mathrm{mg} . / \mathrm{m} .^{3}$ Flasks of 500 c.c. capacity were used, each containing 300 c.c. of the enriched sea water. Phosphorus compounds were supplied giving a phosphorus concentration of $150 \mathrm{mg} . / \mathrm{m} .{ }^{3}$ In culture $\mathrm{A}, \mathrm{KH}_{2} \mathrm{PO}_{4}$ was used; in $\mathrm{B}, \mathrm{Na}_{4} \mathrm{P}_{2} \mathrm{O}_{7}$; and in $\mathrm{C}$, phytin $\left(\mathrm{C}_{12} \mathrm{H}_{22} \mathrm{O}_{44} \mathrm{P}_{10} \mathrm{Ca}_{7} \mathrm{Mg}\right)$. These cultures were 
aerated by bubbling a stream of filtered and washed air through them and equally illuminated by daylight, as they were kept on a rotating table in a north window. Duplicate cultures of $\mathrm{B}$ and $\mathrm{C}(\mathrm{B} d$ and $\mathrm{C} d)$ were stored in the dark in order to check up the change of the phosphorus compounds which is not due to the growth of diatoms.

There was an increasing growth in both cultures A and C during the first 3 days, when the density of the growth, which consisted mainly of Phaeocystis with some chains of Skeletonema costatum, was about the same. The growth in A then stopped, while in C it was still increasing up to the fifth day. The increase was purely due to the increase of Phaeocystis, there being no further increase of Skeletonema costatum cells after the third day. There was no significant growth in culture B during the whole period.

In the sample $\mathrm{B} d$, kept in the dark, a part of the amount of pyrophosphate was found to be turned into orthophosphate, $64 \mathrm{mg} . / \mathrm{m}^{3}$ of orthophosphorus being found, including $7 \mathrm{mg} . / \mathrm{m}^{3}$ present in the original sea water, after 27 days, and 70 and $95 \mathrm{mg} . / \mathrm{m}^{3}$ after 34 and $\mathrm{I} 24$ days respectively. In culture C $d$ some of the added phytin changed to phosphate while kept in the dark. In some other similar storage experiments all the phosphorus in phytin was liberated as orthophosphate in 20 days in the dark, while in yet others it took 4 months.

Distilled water, to which had been added I0,000 mg. pyrophosphate phosphorus per cubic metre, gave a colour corresponding to Io $\mathrm{mg} . / \mathrm{m} .{ }^{3}$ of orthophosphorus $5 \mathrm{~min}$. after adding the reagents when estimated with the Denigés-Atkins method (Atkins, I923). The intensity of the colour increases much more rapidly than in the standard sample within this short period. This indicates that pyrophosphorus turns into orthophosphorus very quickly once the reagents are added. In another 5-10 min. the colour increased to an intensity matching the colour of I6-19 mg. of orthophosphorus per cubic metre. About half an hour after the addition of reagents the colour started decreasing. Full colour developed within $5 \mathrm{~min}$. in the standard. The orthophosphorus content in the pyrophosphate solution before adding the reagents must therefore be much less than Io $\mathrm{mg} . / \mathrm{m}^{3}$ The rate at which pyrophosphate turned into orthophosphate in the presence of the reagents, as judged by the change during the interval from 5 to ro min. after the addition of the reagents, was round about $0.02 \mathrm{mg} . / \mathrm{m} .{ }^{3} / \mathrm{sec}$, though the rate is slightly decreasing. The rate must be greater within 5 min. after adding the reagent. Therefore the orthophosphate in solution, before the addition of the reagent, should have been not more than $4 \mathrm{mg} . / \mathrm{m}^{3}$; and no more than $0.04 \%$ of the calculated amount of phosphorus in the stock solution of pyrophosphate was in the form of orthophosphate. The conversion of pyrophosphate to orthophosphate is purely a chemical reaction in such weak solutions.

It seems clear from this experiment that pyrophosphate does not support any growth of Phaeocystis and Skeletonema. The amount of orthophosphate liberated into the culture together with the original amount in the sea water 
( $7 \mathrm{mg} . / \mathrm{m}^{3}$ ) did not support enough growth to be easily seen on visual inspection. The orthophosphate in culture A (I57 mg. $/ \mathrm{m}^{3}$ ) was depleted in 3 days. Phytin can support longer and larger growths of Phaeocystis than phosphate does when the amount of phosphorus is the same. This seems to show that the growth of this alga, just as that of some blue-green algae, is encouraged by the presence of organic substance.

Exp. 2. In order to ascertain the effect on the growth of Skeletonema costatum when phytin or orthophosphate is supplied as a source of phosphorus, and to make sure whether phosphorus can be utilized by this diatom from pyrophosphate, the above experiment was repeated with sea water which contained Skeletonema costatum as the dominant organism. The orthophosphate concentration in the original sea water was $15 \mathrm{mg} . / \mathrm{m} .^{3}$ Three sets of cultures, A, B and C, were enriched with potassium nitrate, ferric citrate and phosphorus compounds as in Exp. I. Two hours after the sea water was enriched, analysis of orthophosphate gave the result shown in Table I.

\begin{tabular}{|c|c|c|c|c|}
\hline Cultures & P sources & $\begin{array}{l}\text { Amount of } P \\
\text { added } \\
\mathrm{mg} \cdot / \mathrm{m} .^{3}\end{array}$ & $\begin{array}{c}\text { Original ortho-P } \\
\text { in sea water } \\
\text { mg. } / \mathrm{m}^{\mathrm{T}}\end{array}$ & $\begin{array}{l}\text { Ortho-P } \\
\text { found } \\
\mathrm{mg} \cdot / \mathrm{m} .^{3}\end{array}$ \\
\hline $\begin{array}{l}\mathrm{A} \\
\mathrm{B} \\
\mathrm{C}\end{array}$ & $\begin{array}{l}\mathrm{KH}_{2} \mathrm{PO}_{4} \\
\mathrm{Na}_{4} \mathrm{P}_{2} \mathrm{O}_{7} \\
\text { Phytin }\end{array}$ & $\begin{array}{l}150 \\
150 \\
150\end{array}$ & $\begin{array}{l}\text { I5 } \\
15 \\
15\end{array}$ & $\begin{array}{r}163 \\
16 \\
42\end{array}$ \\
\hline
\end{tabular}

The cultures started with 146 cells of Skeletonema costatum per c.c., some Thalassiosira decipiens, a few cells of Coscinodiscus excentricus, and a very few colonies of Phaeocystis Pouchetii. There was little growth in culture B, while in cultures $\mathrm{A}$ and $\mathrm{C}$ there was a continuous and nearly similar increase until the fourth day when the number of cells of Skeletonema costatum was 5100 (A) and 5800 (C) per c.c. The diatom cells retained their healthy appearance the next day and were evenly distributed in the culture. Henceforth they began to sink to the bottom of the culture while Phaeocystis started a remarkable increase in $\mathrm{C}$. On the seventh day nearly all the diatom cells settled on the bottom of the flask. P. Pouchetii flourished only in culture C, and its growth in cultures A and B was very poor.

The result of this experiment confirms that of Exp. I. Phaeocystis grows much better when the culture is supplied with phytin than when it is supplied with orthophosphate. It also shows that Skeletonema grows well when either of these two phosphorus compounds is supplied as a source of phosphorus, but not when pyrophosphate is the only phosphorus compound supplied.

It was not clear why Skeletonema stopped growing in culture C when the medium was still suitable for the growth of Phaeocystis. In order to make sure that there was no shortage of silicate for the growth of diatoms, sodium orthosilicate was added in the following experiment. 
Exp. 3. Sea water from Plymouth Sound was enriched as in the previous experiments, but with further addition of 20 parts per million of $\mathrm{SiO}_{2}$ in the form of sodium orthosilicate. The sea water contained phosphate, $8 \mathrm{mg} . \mathrm{P} / \mathrm{m}^{3}$ Skeletonema seemed to be the only alga present. Growth of Skeletonema was fully developed on the fourth day in cultures A (orthophosphate) and C (phytin), while the growth in B was poor. The growth stopped and the diatoms started to sink to the bottom in cultures A and B, when the orthophosphate left in cultures A, B and C was $4,3.5$, and $2.4 \mathrm{mg} . \mathrm{P} / \mathrm{m}^{3}$ respectively. The growth finished in $\mathrm{C}$ the next day. The result of this experiment is shown in Table II. Phaeocystis did not develop in culture $\mathrm{C}$ in this experiment. It would seem that it did not exist in the sea water used. The end of growth of the diatom in cultures $\mathrm{A}$ and $\mathrm{C}$ seems to be caused not by the lack of silicate, but by the deficiency of available phosphorus. The fact that both phytin and orthophosphate can support much better growths of Skeletonema than pyrophosphate, is again confirmed by this experiment. Phytin supports longer periods of growth of Skeletonema, when it is the only alga growing in the culture, than orthophosphate.

Exp. 4. In this experiment the sea water was first enriched as in Exp. 3, and then sterilized by heating up to $95^{\circ} \mathrm{C}$. and maintaining at this temperature for 20 min. 278 cells of Nitzschia closterium were inoculated from a unialgal culture into each roo c.c. of the culture. The growth was fully developed in 4 days and, as shown in Table III, was good in all the cultures including those to which pyrophosphate was supplied as the only source of phosphorus. The sea water used was filtered through a Berkefeld candle with the filtration apparatus as described by Allen \& Nelson (I9IO, p. 432), and the original content of orthophosphate in the filtered sea water was $5 \mathrm{mg} . \mathrm{P} / \mathrm{m} .^{3}$

This experiment, however, provided no evidence which showed that Nitzschia cells can use pyrophosphate, because more than half of the pyrophosphate was turned into orthophosphate after heating at $95^{\circ} \mathrm{C}$. for $20 \mathrm{~min}$. Phytin was used by Nitzschia as a source of phosphorus as effectively as by Phaeocystis and Skeletonema in the preceding experiments. The liberation of orthophosphate from phytin, when phytin is added to sea water, is partly effected by biological reaction. All the phosphorus in phytin added to a sea-water sample used for the above experiment was turned into orthophosphate after the sample was stored in the dark for 20 days. When a similar sample was heated to $85^{\circ} \mathrm{C}$. before storing in the dark, only 53 out of I $50 \mathrm{mg} . / \mathrm{m} .^{3}$ (i.e. about one-third) of the phosphorus in the amount of phytin added turned into orthophosphate, while in distilled water 66 out of I50 mg. $/ \mathrm{m}^{3}$ (i.e. a little less than one-half) of the phosphorus in phytin was turned into orthophosphate after storing in the dark for 20 days. It would seem, therefore, that phytin in such a low concentration is partly decomposed in sterile solution into orthophosphate, and that the rate of this chemical process is greater in distilled water than in sea water. When the Nitzschia cells in the unialgal culture were filtered off through filter paper (Whatman No. 54I) 
Table II. Growth of SKELETonema COStatum IN $\mathrm{KH}_{2} \mathrm{PO}_{4}, \mathrm{Na}_{4} \mathrm{P}_{2} \mathrm{O}_{7}$ and Phytin

\begin{tabular}{|c|c|c|c|c|c|c|c|}
\hline \multirow[b]{2}{*}{ Cultures } & \multirow[b]{2}{*}{ P compounds } & \multirow{2}{*}{$\begin{array}{l}\text { Initial conc. of } \mathrm{P}, \\
\mathrm{mg} \cdot / \mathrm{m} .^{3}\end{array}$} & \multirow[b]{2}{*}{4 days } & \multicolumn{2}{|l|}{5 days } & \multicolumn{2}{|c|}{6 days } \\
\hline & & & & & Ortho-P & & Ortho-P \\
\hline A & $\mathrm{KH}_{2} \mathrm{PO}_{4}$ & 158 & $\begin{array}{l}\text { Growth fully developed, } \\
\text { very good }\end{array}$ & $\begin{array}{l}\text { Growth stopped, and } \\
\text { sedimented }\end{array}$ & $4.0 \mathrm{mg} . / \mathrm{m}^{3}$ & Sedimented & $3 \mathrm{mg} \cdot / \mathrm{m}^{3}$ \\
\hline B & $\mathrm{Na}_{4} \mathrm{P}_{2} \mathrm{O}_{7}$ & 158 & Poor & Do. & $3.5 \mathrm{mg} . / \mathrm{m}^{3}$ & Sedimented & $2 \mathrm{mg} . / \mathrm{m}^{3}$ \\
\hline $\mathrm{C}$ & Phytin & 158 & $\begin{array}{l}\text { Growth fully developed, } \\
\text { very good }\end{array}$ & $\begin{array}{l}\text { Rate of growth much } \\
\text { dečreased, cells be- } \\
\text { ginning to sink }\end{array}$ & $2.4 \mathrm{mg} . / \mathrm{m}^{3}$ & Sedimented & $6 \mathrm{mg} \cdot / \mathrm{m}^{3}$ \\
\hline
\end{tabular}

Table IV. Growth of Nitzschia closterium in Bacteria-free Cultures when Phosphorus was Supplied in Different Forms

\begin{tabular}{|c|c|c|c|c|c|c|c|c|c|c|c|c|c|}
\hline \multirow[b]{2}{*}{ Cultures } & \multirow[b]{2}{*}{$\begin{array}{c}\mathrm{P} \\
\text { compounds }\end{array}$} & \multirow{2}{*}{$\begin{array}{l}\text { Initial } \\
\text { ortho-P } \\
\mathrm{mg} . / \mathrm{m} .^{3}\end{array}$} & \multirow{2}{*}{$\begin{array}{c}\text { Initial } \\
\text { no. cells } \\
\text { per c.c. }\end{array}$} & \multicolumn{2}{|c|}{9 days } & \multicolumn{2}{|c|}{ II days } & \multicolumn{2}{|c|}{13 days } & \multicolumn{2}{|c|}{ I8 days } & \multicolumn{2}{|c|}{20 days } \\
\hline & & & & $\begin{array}{l}\text { Ortho-P } \\
\mathrm{mg} . / \mathrm{m} .^{3}\end{array}$ & $\begin{array}{l}\text { No. of cells } \\
\text { per c.c. }\end{array}$ & $\begin{array}{l}\text { Ortho-P } \\
\mathrm{mg} . / \mathrm{m} .^{3}\end{array}$ & $\begin{array}{l}\text { No. of cells } \\
\text { per c.c. }\end{array}$ & $\begin{array}{l}\text { Ortho-P } \\
\mathrm{mg} . / \mathrm{m} .^{3}\end{array}$ & $\begin{array}{l}\text { No. of cells } \\
\text { per c.c. }\end{array}$ & $\begin{array}{l}\text { Ortho-P } \\
\mathrm{mg} . / \mathrm{m} .^{3}\end{array}$ & $\begin{array}{l}\text { No. of cells } \\
\text { per c.c. }\end{array}$ & $\begin{array}{l}\text { Ortho-P } \\
\mathrm{mg} \cdot / \mathrm{m} .^{3}\end{array}$ & $\begin{array}{l}\text { No. of cells } \\
\text { per c.c. }\end{array}$ \\
\hline Set A & Ortho-P & 208 & 860 & 3.0 & 454,000 & $2 \cdot 5$ & 844,000 & $2 \cdot 0$ & 845,000 & $2 \cdot 0$ & 845,000 & $2 \cdot 0$ & 845,000 \\
\hline Set B & Pyro-P & 9 & 860 & $10 \cdot 0$ & 72,000 & $3 \cdot 0$ & 224,000 & 2.5 & 594,000 & $2 \cdot 0$ & 844,000 & $2 \cdot 0$ & 544,000 \\
\hline Set C & Phytin & 45 & 860 & 2.5 & 632,000 & 2.5 & 734,000 & $2 \cdot 0$ & 836,000 & $2 \cdot 0$ & $\mathrm{I}, \mathrm{I} 22,000$ & $2 \cdot 0$ & $\mathrm{I}, \mathrm{I} 22,000$ \\
\hline
\end{tabular}


TAble III. Growth of Nitzschia CLOSTERIUM when Phosphorus WAS SUPPLIED IN DifFerent FormS

\begin{tabular}{|c|c|c|c|c|c|}
\hline Cultures & $\begin{array}{l}\mathrm{P} \text { added } \\
\mathrm{mg} . / \mathrm{m}^{3}\end{array}$ & & $\begin{array}{l}3 \text { days } \\
\text { no. of cells }\end{array}$ & $\begin{array}{l}4 \text { days } \\
\text { no. of cells }\end{array}$ & $\begin{array}{l}\text { Ortho-P left } \\
\mathrm{mg} . / \mathrm{m}^{3}\end{array}$ \\
\hline I & Ortho-P & I5O & 15,500 & 85,000 & $2 \mathrm{I}$ \\
\hline 2 & Ortho-P & 150 & 16,000 & 100,000 & 20 \\
\hline 3 & Pyro-P & 150 & I 1,000 & 56,000 & 9 \\
\hline 4 & Pyro-P & 150 & 10,000 & 58,000 & 6 \\
\hline 5 & $\begin{array}{l}\text { Ortho-P } \\
\text { and pyro-P }\end{array}$ & $\begin{array}{l}75 \\
75\end{array}$ & 13,150 & 80,000 & 13 \\
\hline 6 & $\begin{array}{l}\text { Ortho-P } \\
\text { and pyro-P }\end{array}$ & $\begin{array}{l}75 \\
75\end{array}$ & $\mathrm{I} 4, \mathrm{I} 5 \mathrm{O}$ & 80,000 & I0 \\
\hline 7 & Phytin-P & 150 & 20,000 & 40,000 & 38 \\
\hline 8 & Phytin-P & 150 & 22,000 & II 8,000 & 35 \\
\hline
\end{tabular}

and the filtrate was inoculated into the culture medium containing phytin, all the phosphorus in phytin was also turned into orthophosphate after the sample was stored in the dark for 20 days. If one-third of the amount of orthophosphate liberated is due to pure chemical reaction, two-thirds must be due to the effect of bacteria, as there were no Nitzschia cells in the sample.

Good growth was obtained in unialgal cultures of Skeletonema costatum and Nitzschia closterium when glycerophosphoric acid, sodium nucleinate and lecithin were supplied singly as a source of phosphorus. These organic phosphorus compounds, however, were also found to be broken down into orthophosphate in the presence of bacteria in the sea water.

It was advisable therefore to experiment on bacteria-free cultures so that the reaction due to bacteria might be avoided. Hence a bacteria-free culture of Nitzschia closterium forma minutissima was made, starting from single cells isolated from the unialgal culture. The method used is described in another paper (Chu, I946).

Exp. 5. Half a c.c. of the bacteria-free culture of Nitzschia containing 430,000 cells was inoculated into each of the 500 c.c. cultures in Berkefeld filtered sea water which had been enriched with $2000 \mathrm{mg} . / \mathrm{m} .^{3}$ of nitrate nitrogen, $2 \mathrm{mg} . / \mathrm{m} .^{3}$ of iron in the form of citrate, $2000 \mathrm{mg} . / \mathrm{m}^{3}$ of $\mathrm{SiO}_{2}$ and $200 \mathrm{mg}$. $/ \mathrm{m}^{3}$ of phosphorus supplied in different forms in different sets of cultures. The media were sterilized the day before inoculation by heating at $95^{\circ} \mathrm{C}$. for $15 \mathrm{~min}$. The stock solutions of phosphorus compounds were sterilized at $95^{\circ} \mathrm{C}$. for $15 \mathrm{~min}$., and the required amount, containing $0 . \mathrm{I} \mathrm{mg}$. of phosphorus, was added to each 500 c.c. of the medium just before the latter was inoculated with bacteria-free Nitzschia cells. The sources of phosphorus are $\mathrm{KH}_{2} \mathrm{PO}_{4}$ in culture set $\mathrm{A}, \mathrm{Na}_{4} \mathrm{P}_{2} \mathrm{O}_{7}$ in set $\mathrm{B}$, and phytin in set $\mathrm{C}$, each set containing four duplicate cultures. One culture from each set was kept in an incubator at $22^{\circ} \mathrm{C}$. after adding $\mathrm{I} \%$ of sterilized peptone. The stock solution of peptone was sterilized by autoclaving for I hr. at $20 \mathrm{lb}$. pressure. Boiling for half an hour is not enough to kill bacterial spores, as bacteria growth occurred in the peptone solution so treated after having been kept in the incubator at $22^{\circ} \mathrm{C}$. 
The phosphorus content in phytin, as estimated by first wet ashing with sulphuric acid and perhydrol and then treating with the acid molybdate reagent (allowing for the amount of acid already present), was found to be the same as that calculated from the formula $\mathrm{C}_{12} \mathrm{H}_{22} \mathrm{O}_{44} \mathrm{P}_{10} \mathrm{Ca}_{7} \mathrm{Mg}$. When the stock solution of phytin ( $\mathrm{I} \mathrm{mg.} \mathrm{P} \mathrm{in} \mathrm{I} \mathrm{c.c.)} \mathrm{was} \mathrm{diluted} \mathrm{Io} \mathrm{times,} 0.14 \%$ of the total phosphorus was found to be in the form of orthophosphate. The phosphorus content of pyrophosphate was also found to be the same as shown by the formula $\mathrm{Na}_{4} \mathrm{P}_{2} \mathrm{O}_{7}$, and when the stock solution ( $\mathrm{I}$ mg. $\mathrm{P}$ in I c.c.) was diluted Io times, $0.0075 \%$ of the total phosphorus was found to be in the form of orthophosphate. The content of orthophosphate phosphorus, as estimated just before the inoculation of the cultures, is recorded in Table IV. The phosphate phosphorus content of the original sea water used was $7 \mathrm{mg} . / \mathrm{m} .^{3}$

One culture of each set was put on a revolving table, so that equal illumination was assured, while the other two cultures of each set were put near a north window. Noticeable growth was observed in culture sets A and C. In set $\mathrm{B}$, the cultures showed no significant growth during the first 7 days, and only a slight growth was observed after 8 days; but the growth was increasing rapidly afterwards.

There was no growth of bacteria in the cultures kept in the incubator. Sterilized peptone was added to one of the illuminated cultures ( 20 days old) from each set, which were then incubated at $22^{\circ} \mathrm{C}$. No growth of bacteria occurred.

Duplicate cultures of sets B and C were kept in the dark as a check to ascertain the amount of orthophosphate formed from pyrophosphate and phytin. $48 \mathrm{mg} . / \mathrm{m}^{3}$ of orthophosphate were found in sample B (pyrophosphate) and $7 \mathrm{I} \mathrm{mg./m.} .^{3}$ of orthophosphate in sample $\mathrm{C}$ (phytin) in 20 days. Therefore $39(\mathrm{I} 8 \%)$ and $26(13 \%) \mathrm{mg} . / \mathrm{m}^{3}$ of orthophosphate were liberated from pyrophosphate and phytin in samples $\mathrm{B}$ and $\mathrm{C}$ respectively during this period. If the same amounts of orthophosphate were liberated in the illuminated cultures, it would seem that most of the phosphorus consumed was in the form of pyrophosphate in B and organic phosphorus in C. However, the delay of the growth in the cultures in set B evidently shows that pyrophosphate cannot, at least, be utilized as effectively as orthophosphate; then the later rapid growth in these cultures seems to show that more orthophosphate was liberated at that time, probably in some way due to the presence of the increasing number of cells in the cultures. The initial rapid growth in cultures of set C, which is about the same as in those of set A, shows that the phosphorus from phytin can be used as effectively as orthophosphate.

Exp. 6. In this experiment glycerophosphoric acid was used as a source of phosphorus $\left(400 \mathrm{mg} . / \mathrm{m}^{3}\right)$. The sea water was first enriched with nitrate, ferric citrate, and silicate as in the previous experiments, and then sterilized and inoculated with $N$. closterium (700,000 cells in each 500 c.c. culture) from a bacteria-free culture. A parallel set of cultures was made using orthophosphate. This experiment was carried out in daylight during December 
Table V. Growth of Bacteria-free Cultures of N. closterium in Glycerophosphoric Acid (A), and in Orthophosphate (B). (Average of Two Cultures from each Set. Original Orthophosphate Content was $6 \mathrm{mg} . / \mathrm{m}^{3}$ )

\begin{tabular}{|c|c|c|c|c|c|c|c|c|c|c|c|c|}
\hline \multirow[b]{2}{*}{ Cultures } & \multirow[b]{2}{*}{ Sources of $\mathrm{P}$} & \multirow{2}{*}{$\begin{array}{l}\text { Inoculum } \\
\text { cells } \\
\text { per c.c. }\end{array}$} & \multirow[b]{2}{*}{$\begin{array}{l}\text { Total P } \\
\mathrm{mg} . / \mathrm{m}^{3}\end{array}$} & \multirow{2}{*}{$\begin{array}{l}\text { Initial } \\
\text { ortho-P } \\
\mathrm{mg} . / \mathrm{m} .^{3}\end{array}$} & \multicolumn{2}{|c|}{7 days } & \multicolumn{2}{|c|}{ I3 days } & \multicolumn{2}{|c|}{24 days } & \multicolumn{2}{|c|}{39 days } \\
\hline & & & & & $\begin{array}{l}\text { Ortho-P } \\
\mathrm{mg} \cdot \mathrm{m}^{3}\end{array}$ & $\begin{array}{l}\text { No. of cells } \\
\text { per c.c. }\end{array}$ & $\begin{array}{l}\text { Ortho-P } \\
\mathrm{mg} \cdot \mathrm{m}^{3}\end{array}$ & $\begin{array}{l}\text { No. of cells } \\
\text { per c.c. }\end{array}$ & $\begin{array}{l}\text { Ortho-P } \\
\text { mg. } / \mathrm{m}^{3}{ }^{3}\end{array}$ & $\begin{array}{l}\text { No. of cells } \\
\text { per c.c. }\end{array}$ & $\begin{array}{l}\text { Ortho-P } \\
\text { mg. } / \mathrm{m}^{3}{ }^{3}\end{array}$ & $\begin{array}{l}\text { No. of cells } \\
\text { per c.c. }\end{array}$ \\
\hline A & $\begin{array}{l}\text { Glycerophosphoric } \\
\text { acid }\end{array}$ & 1400 & 406 & 12 & 25 & 2,460 & ○ & 112,500 & $\circ$ & 685,000 & $\circ$ & $2,120,000$ \\
\hline B & Orthophosphate & 1400 & 406 & 406 & 190 & 3,840 & 90 & 129,500 & o & 500,000 & ० & $2,100,000$ \\
\hline
\end{tabular}

Table Vi. Growth of N. Closterium in Bacteria-Free Cultures Supplied with Sodium Nucleinate (Set A, P=200 mg. $/ \mathrm{m}^{3}$ ) and Orthophosphate (Set B, $\mathrm{P}=200 \mathrm{mg} . / \mathrm{m}^{3}{ }^{3}$ ). Original Orthophosphate Phosphorus Content in the Sea Water used was 5 mg./m. ${ }^{3}$

\begin{tabular}{|c|c|c|c|c|c|c|c|c|c|c|c|c|c|}
\hline \multirow[b]{2}{*}{$\begin{array}{l}\text { Cul- } \\
\text { tures }\end{array}$} & \multirow[b]{2}{*}{$\begin{array}{l}\text { Sources } \\
\text { of } P\end{array}$} & \multirow{2}{*}{$\begin{array}{l}\text { Initial } \\
\text { ortho-P } \\
\text { mg./m. }\end{array}$} & \multirow[b]{2}{*}{ Inoculum } & \multicolumn{2}{|c|}{5 days } & \multicolumn{2}{|c|}{8 days } & \multicolumn{2}{|c|}{ II days } & \multicolumn{2}{|c|}{ 2I days } & \multicolumn{2}{|c|}{38 days } \\
\hline & & & & $\begin{array}{l}\text { Ortho-P } \\
\mathrm{mg} \cdot / \mathrm{m} .^{3}\end{array}$ & $\begin{array}{l}\text { No. of cells } \\
\text { per c.c. }\end{array}$ & $\begin{array}{l}\text { Ortho-P } \\
\mathrm{mg} . / \mathrm{m} \cdot{ }^{3}\end{array}$ & $\begin{array}{l}\text { No. of cells } \\
\text { per c.c. }\end{array}$ & $\begin{array}{l}\text { Ortho-P } \\
\mathrm{mg} . / \mathrm{m} .^{3}\end{array}$ & $\begin{array}{l}\text { No. of cells } \\
\text { per c.c. }\end{array}$ & $\begin{array}{l}\text { Ortho-P } \\
\mathrm{mg} . / \mathrm{m} .^{3}\end{array}$ & $\begin{array}{l}\text { No. of cells } \\
\text { per c.c. }\end{array}$ & $\begin{array}{l}\text { Ortho-P } \\
\mathrm{mg} . / \mathrm{m}^{3}\end{array}$ & $\begin{array}{l}\text { No. of cells } \\
\text { per c.c. }\end{array}$ \\
\hline Set A & Nucleinate & 5 & 15,300 & 4 & 50,400 & o & 218,000 & ० & 370,000 & 0 & 360,000 & o & 360,000 \\
\hline Set $B$ & $\begin{array}{l}\text { Orthophos- } \\
\text { phate }\end{array}$ & 205 & 15,300 & 180 & 48,000 & 5 & 390,000 & 3 & 686,000 & 2 & I,980,000 & o & $\mathrm{I}, 980,000$ \\
\hline
\end{tabular}


and January, and the growth was much slower because of the rather poor illumination. Table $\mathrm{V}$ embodies the result of this experiment.

When $400 \mathrm{mg} . / \mathrm{m}^{3}$ of phosphorus as glycerophosphoric acid were added to the sea water used, $\mathrm{I} \cdot 6 \%$ of the phosphorus was found to be in the form of orthophosphate. Very slight or no increase of orthophosphate was found after autoclaving. In the duplicate cultures with inoculum, which were kept in the dark for Io days, no more than $5 \%$ of the phosphorus was turned into orthophosphate. Therefore the phosphorus from glycerophosphoric acid must be used for the main bulk of the growth in cultures of set A. The growth in this set of cultures was more or less the same as that in cultures of set B supplied with orthophosphate. This indicates that glycerophosphoric acid can be used as a source of phosphorus as good as orthophosphate for the growth of this diatom. The diatom cells in cultures of set A were found to be able to divide as many as nine times when no orthophosphorus was detectable in the culture.

Exp. 7. This experiment was carried out in the hope of finding out whether sodium nucleinate can be used as a source of phosphorus in bacteria-free cultures of $N$. closterium. This compound is very stable and no change into orthophosphate occurred after it was added to the sterilized enriched sea water and kept for 5 days. As can be seen from Table VI, which embodies the growth in cultures of set A (average of three cultures) using sodium nucleinate as a source of phosphorus and that in cultures of set B supplied with orthophosphate, very little growth was obtained when nucleinate is supplied. It is clear that sodium nucleinate cannot be used as a source of phosphorus by this diatom.

Exp. 8. Lecithin was tried in cultures in a similar way as in the above experiment. No growth was obtained when it is supplied as the only source of phosphorus, and evidently it cannot be used by $N$. closterium in bacteria-free cultures. It is very stable, and very little, or none at all, is turned into orthophosphate in sterilized sea water.

It is clear from the above experiments that in bacteria-free cultures the marine diatom $N$. closterium forma minutissima can utilize phosphorus from some organic compounds such as phytin and glycerophosphoric acid, though not from some others such as lecithin and nucleic acid. The latter have been reported as utilizable sources of phosphorus for higher plants (Stoklasa, I896; Schreiner, I923). Further investigation is needed as to why they cannot be utilized by this diatom. In order to find out whether the phosphorus dissolved out from marine algae can be effectively utilized by this diatom in bacteria-free cultures, the following investigation was made.

Exp. 9. Square pieces were cut off from fresh fronds of Laminaria saccharina collected near low-water mark (about I year old), and the blade surface was dried with blotting paper and weighed. Then they were dried in an oven at $100^{\circ} \mathrm{C}$. until there was no further decrease in the weight. The water content of the fronds was found on the average to be $84 \%$ of the fresh weight. The 
total phosphorus as estimated by wet ashing with sulphuric acid and perhydrol after the method used by Cooper (I934, p. 756) varies from 0.3 to $0.4 \%$ of the dry weight in different plants and different parts of the fronds. The amount of totai phosphorus in the fresh fronds collected from a craft was much larger, being I \% of the dry weight.

When extracted with distilled water in a hot water bath for $24 \mathrm{hr} ., 8 \cdot 2 \%$ of the total phosphorus was dissolved out into the solution, $2 \%$ being in the form of orthophosphate and $6.2 \%$ in the form of organic material, while $80 \%$ of the total phosphorus of the moribund fronds, which had been kept in the laboratory tank for a week, was found to be soluble as orthophosphorus.

Parallel bacteria-free Nitzschia cultures were made in Berkefeld filtered sea water, which was enriched with nitrogen, iron and silica as in previous experiments. In one set of cultures (A) the phosphorus was supplied as orthophosphate, and in another set (B) it was supplied as hot-water extract of fresh Laminaria fronds, the phosphorus added in both sets of cultures being in all $400 \mathrm{mg} . / \mathrm{m}^{3}$

The resulting growth of cultures in set B was as good as that in set A. As only $2 \%$ of the phosphorus in the Laminaria extract added to cultures of set B was in the form of orthophosphate, it may be assumed that the phosphorus used by Nitzschia cells in these cultures was mainly in the organic form.

\section{SUMMARY AND CONCLUSION}

Cultural experiments were made with marine organisms in enriched crude sea water and in bacteria-free cultures with the phosphorus supplied in different forms. It was found that pyrophosphate cannot be utilized as a source of phosphorus as effectively as orthophosphate by the organisms cultured, i.e. Phaeocystis Pouchetii, Skeletonema costatum and Nitzschia closterium. Growth of Phaeocystis Pouchetii was a little better and lasted longer when phytin was supplied to natural sea water as a source of phosphorus than when orthophosphate was supplied. Phytin can also support a growth of Skeletonema costatum and Nitzschia closterium as good as, or a little better than, orthophosphate.

The organic phosphorus compounds used in these experiments were found to be broken down into orthophosphate in natural sea water. In bacteria-free cultures phytin and glycerophosphoric acid can be effectively used as such by Nitzschia closterium forma minutissima as a source of phosphorus, while sodium nucleinate and lecithin can not be effectively used as such. The organic phosphorus dissolved out from the blades of Laminaria can also be utilized by this diatom as effectively as orthophosphorus.

It would seem, therefore, that not only the dissolved orthophosphate as generally assumed, but the dissolved organic phosphorus in the sea may also be absorbed and utilized by plants. Thus the change of the dissolved organic phosphorus in the sea may follow two courses, (I) turning into orthophosphate 
and (2) being absorbed and utilized by living organisms; and the essential feature of the phosphorus cycle would be as in the following diagram.

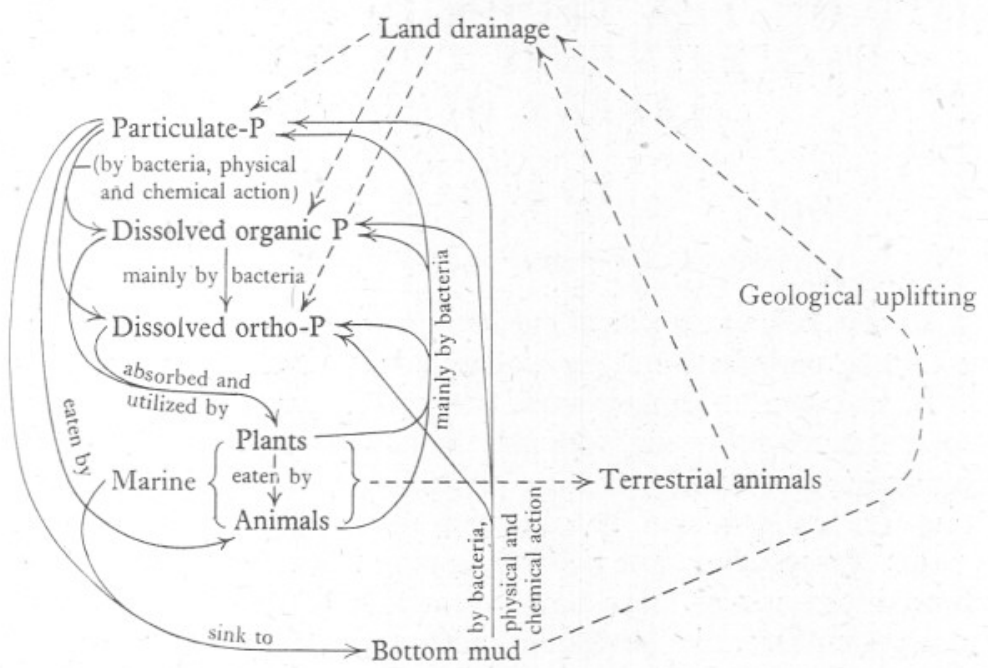

The foregoing research was carried out while holding a Ray Lankester Investigatorship at the laboratory of the Marine Biological Association at Plymouth. The author is very much indebted to Dr H. W. Harvey, F.R.S., for his valuable suggestions and helpfulness during this investigation.

\section{REFERENCES}

Allen, E. J. \& Nelson, E. W., r9ro. On the artificial culture of marine plankton organisms. Fourn. Mar. Biol, Assoc., Vol. vIII, pp. 42I-74.

Atrins, W. R. G., I923. The phosphate content of fresh and salt waters in its relationship to the growth of algal plankton. Fourn. Mar. Biol. Assoc., Vol. xIII, pp. II9-50.

CHU, S. P., I946. Note on the technique of making bacteria-free cultures of marine diatoms. Fourn. Mar. Biol. Assoc., Vol. xxvi, pp. 296-302).

Cooper, L. H. N., I934. The determination of phosphorus and nitrogen in plankton. Fourn. Mar. Biol. Assoc., Vol. xIx, pp. 755-9.

- I937. The nitrogen cycle in the sea. Fourn. Mar. Biol. Assoc., Vol. xxir, pp. $183-204$.

HARVEY, H. W., I940. Nitrogen and phosphorus required for the growth of phytoplankton. Fourn. Mar. Biol. Assoc., Vol. xvII, pp. II 5-23.

- I942. Production of life in the sea. Biol. Rev., Vol. I7, pp. 22 I-46.

SchreIner, O., I923. Organic phosphorus in soils. Fourn. Amer. Soc. Agron., Vol. I5: pp. II $7-25$.

STOKLASA, J., I896. Úber die Verbreitung und physiologische Bedeutung des Lecithins in der Pflanze. Sitzungsber. K. Akad. Wiss. Wien, Bd. cv, p. 604 . 